\title{
CMEARTICLE \\ Doctor, do I really need treatment for my current blood pressure?
}

Choon How $\underline{H o w}^{1}$, MMed, FCFP, Hui Min Joanne $\underline{\text { Quah }}{ }^{2}$, MMed, FCFP

\begin{abstract}
Mr and Mrs Wolfgang had been recommended to your clinic for a second opinion concerning their blood pressure targets. The memo from your fellow family physician noted a trend of systolic blood pressure readings of 131-139 $\mathrm{mmHg}$ and diastolic blood pressure readings of 81-88 $\mathrm{mmHg}$ for both patients in the last four visits over the past 12 months. Mr Wolfgang had well-controlled diabetes mellitus, while Mrs Wolfgang did not have any chronic medical condition. The couple felt that their pressure readings were tolerable for people in their seventies and was not keen to start on any antihypertensive medications.
\end{abstract}

\section{WHAT IS HYPERTENSION?}

Hypertension, also known as high or raised blood pressure, is a global health issue with potential risk for long-term cardiovascular and renal complications. ${ }^{(1)}$ Patients rarely experience symptoms in the early stages of hypertension and many go undiagnosed. The majority of patients with hypertension are treated by primary care physicians.

Blood pressure is measured in millimetres of mercury $(\mathrm{mmHg})$ and recorded as the upper number or systolic (highest pressure in blood vessels when the heart squeezes) over the lower number or diastolic (lowest blood pressure in blood vessels when the heart relaxes). As there can be large spontaneous variations in blood pressure, hypertension is diagnosed based on multiple systolic blood pressure readings above $140 \mathrm{mmHg}$ or diastolic blood pressure readings above $90 \mathrm{mmHg}$ taken on several separate occasions. ${ }^{(2)}$

\section{HOW RELEVANT IS THIS TO MY PRACTICE?}

In Singapore, the 2010 National Health Survey showed a slight decrease in crude prevalence of hypertension, from $27.3 \%$ in 1998 to $24.9 \%$ in 2004 and $23.5 \%$ in 2010 (Table I). ${ }^{(3)}$ In 2014, the Joint National Committee (JNC) published the latest guideline for high blood pressure management, providing a summary of the current available evidencebased recommendations for our practising reference, in the absence of any local guidelines (the withdrawn Ministry of Health clinical practice guidelines for hypertension was dated 2005).

\section{CLINICAL APPROACH TO HYPERTENSION}

Differences in approach to the current available evidence between JNC 7 and JNC 8

The JNC $8^{(4)}$ approached the medical literature with a limited number of questions judged to be of the highest priority and restricted the initial systematic review to only randomised controlled trials (Table II). The JNC 7, on the other hand, addressed multiple issues and reviewed a range of study designs.

Table I. Prevalence (\%) of hypertension by gender and ethnic group in 1992, 1998, 2004 and $2010 .^{(3)}$

\begin{tabular}{|c|c|c|c|c|c|c|c|c|}
\hline \multirow{2}{*}{$\begin{array}{l}\text { Gender/ } \\
\text { ethnic group }\end{array}$} & \multicolumn{4}{|c|}{ Crude prevalence } & \multicolumn{4}{|c|}{ Age-standardised prevalence $(95 \% \mathrm{CI})$} \\
\hline & 1992 & 1998 & 2004 & 2010 & 1992 & 1998 & 2004 & 2010 \\
\hline Total & 22.2 & 27.3 & 24.9 & 23.5 & $27.7(25.9,29.5)$ & $32.5(30.9,34.1)$ & $26.8(25.3,28.4)$ & $23.5(21.9,25.1)$ \\
\hline Male & 25.7 & 30.5 & 29.5 & 26.4 & $31.4(28.8,34.0)$ & $35.3(33.1,37.6)$ & $25.9(29.1,33.7)$ & $26.4(24.0,28.8)$ \\
\hline Female & 18.7 & 24.0 & 20.4 & 20.7 & $24.0(21.6,26.4)$ & $29.6(27.4,31.7)$ & $22.3(20.3,24.4)$ & $20.7(18.7,22.7)$ \\
\hline \multicolumn{9}{|l|}{ Ethnic group } \\
\hline Chinese & 22.1 & 26.9 & 25.6 & 23.4 & $27.5(25.5,29.4)$ & $31.7(30.0,33.4)$ & $27.1(25.4,28.9)$ & $23.4(20.7,26.1)$ \\
\hline Malay & 24.0 & 31.5 & 22.7 & 28.0 & $31.1(25.9,36.3)$ & $40.5(35.9,45.1)$ & $25.1(20.7,29.5)$ & $28.0(25.6,30.4)$ \\
\hline Indian & 21.2 & 24.6 & 21.6 & 19.3 & $24.5(18.1,30.8)$ & $29.4(23.9,35.0)$ & $24.1(18.9,29.4)$ & $19.3(16.0,22.6)$ \\
\hline
\end{tabular}

$\mathrm{Cl}$ : confidence interval 
Table II. The nine key recommendations of Joint National Committee (JNC) 8. $^{(4)}$

\begin{tabular}{|c|c|c|}
\hline No. & JNC 8 recommendation & Other recommendations \\
\hline 1 & $\begin{array}{l}\text { For patients aged } \geq 60 \mathrm{yrs} \text {, initiate pharmacologic treatment to lower BP at } \\
\mathrm{SBP} \geq 150 \mathrm{mmHg} \text { or } \mathrm{DBP} \geq 90 \mathrm{mmHg} \text {, and treat to a goal SBP }<150 \mathrm{mmHg} \\
\text { and goal } \mathrm{DBP}<90 \mathrm{mmHg} \text {. }\end{array}$ & $\begin{array}{l}\text { JNC } 8 \text { corollary recommendation: For } \\
\text { patients aged } \geq 60 \text { yrs, if pharmacologic } \\
\text { treatment for high BP results in lower } \\
\text { achieved SBP (e.g. }<140 \mathrm{mmHg} \text { ) and } \\
\text { treatment is well tolerated without } \\
\text { adverse effects on health or quality } \\
\text { of life, treatment does not need to be } \\
\text { adjusted. }\end{array}$ \\
\hline 2 & $\begin{array}{l}\text { For patients aged }<60 \mathrm{yrs} \text {, initiate pharmacologic treatment to lower BP at } \\
\text { DBP } \geq 90 \mathrm{mmHg} \text {, and treat to a goal DBP }<90 \mathrm{mmHg} \text {. }\end{array}$ & \\
\hline 3 & $\begin{array}{l}\text { For patients aged }<60 \text { years, initiate pharmacologic treatment to lower BP } \\
\text { at } \mathrm{SBP} \geq 140 \mathrm{mmHg} \text {, and treat to a goal SBP }<140 \mathrm{mmHg} \text {. }\end{array}$ & \\
\hline 4 & $\begin{array}{l}\text { For patients aged } \geq 18 \text { years with } \mathrm{CKD} \text {, initiate pharmacologic treatment } \\
\text { to lower } \mathrm{BP} \text { at } \mathrm{SBP} \geq 140 \mathrm{mmHg} \text { or } \mathrm{DBP} \geq 90 \mathrm{mmHg} \text {, and treat to a goal } \\
\mathrm{SBP}<140 \mathrm{mmHg} \text { and goal } \mathrm{DBP}<90 \mathrm{mmHg} \text {. }\end{array}$ & \\
\hline 5 & $\begin{array}{l}\text { For patients aged } \geq 18 \text { years with diabetes mellitus, initiate pharmacologic } \\
\text { treatment to lower BP at SBP } \geq 140 \mathrm{mmHg} \text { or } \mathrm{DBP} \geq 90 \mathrm{mmHg} \text {, and treat to } \\
\text { a goal SBP }<140 \mathrm{mmHg} \text { and goal } \mathrm{DBP}<90 \mathrm{mmHg}^{*}\end{array}$ & $\begin{array}{l}\text { MOH CPG on Diabetes Mellitus } 2014 \text { : } \\
\text { For patients with type } 2 \text { diabetes } \\
\text { mellitus, a treatment-initiation and } \\
\text { target goal of SBP }<140 \mathrm{mmHg} \text { and goal } \\
\text { DBP }<80 \mathrm{mmHg} \text { is acceptable. }{ }^{(5)}\end{array}$ \\
\hline 6 & $\begin{array}{l}\text { For patients in the general nonblack population, including those with } \\
\text { diabetes mellitus, initial antihypertensive treatment should include a } \\
\text { thiazide-type diuretic, CCB, ACEI or ARB. }\end{array}$ & $\begin{array}{l}\text { MOH CPG on Diabetes Mellitus 2014: } \\
\text { ACEI or ARB should be included as } \\
\text { part of the antihypertensive regimen }\end{array}$ \\
\hline 7 & $\begin{array}{l}\text { For patients in the general black population, including those with diabetes } \\
\text { mellitus, initial antihypertensive treatment should include a thiazide-type } \\
\text { diuretic or CCB. }\end{array}$ & $\begin{array}{l}\text { for people with type } 2 \text { diabetes } \\
\text { mellitus requiring pharmacotherapy } \\
\text { for hypertension, unless it is not well } \\
\text { tolerated. }{ }^{(5)}\end{array}$ \\
\hline 8 & $\begin{array}{l}\text { For patients aged } \geq 18 \text { years with CKD, initial (or add-on) antihypertensive } \\
\text { treatment should include ACEI or ARB to improve kidney outcomes. This } \\
\text { applies to all CKD patients with hypertension regardless of race or status of } \\
\text { diabetes mellitus. }\end{array}$ & \\
\hline 9 & $\begin{array}{l}\text { The main objective of hypertension treatment is to attain and maintain a } \\
\text { goal BP. If the goal BP is not reached within a month of treatment, increase } \\
\text { the dose of the initial drug or add a second drug from one of the classes in } \\
\text { recommendation (thiazide-type diuretic, CCB, ACEI, or ARB). The clinician } \\
\text { should continue to assess BP and adjust the treatment regimen until the } \\
\text { goal BP is reached. If the goal BP cannot be reached with two drugs, add } \\
\text { and titrate a third drug from the list provided. Do not use ACEI and ARB } \\
\text { together in the same patient. If the goal BP cannot be reached using only } \\
\text { the drugs recommended because of a contraindication, or more than } \\
\text { three drugs are needed to reach the goal BP, antihypertensive drugs from } \\
\text { other classes can be used. Referral to a hypertension specialist may be } \\
\text { indicated for patients in whom the goal BP cannot be attained using the } \\
\text { above strategy or for complicated patients for whom additional clinical } \\
\text { consultation is needed. }\end{array}$ & \\
\hline
\end{tabular}

*The difference in the recommendations for DBP targets arose from the inclusion of other study designs in the overall consideration. ACEI: angiotensin-convertingenzyme inhibitor; ARB: angiotensin receptor blocker; BP: blood pressure; CCB: calcium channel blocker; CKD: chronic kidney disease; CVD: cardiovascular disease; DBP: diastolic blood pressure; ESRD: end-stage renal disease; GFR: glomerular filtration rate; HF: heart failure; MOH CPG: Ministry of Health Clinical Practice Guidelines; SBP: systolic blood pressure

\section{TAKE HOME MESSAGES}

1. Hypertension, also known as high or raised blood pressure, is a global health issue with a potential risk for long-term cardiovascular and renal complications.

2. For adults aged $<60$ years, hypertension medications should be recommended when systolic and diastolic blood pressures are $>140 \mathrm{mmHg}$ and $>90 \mathrm{mmHg}$, respectively.

3. For adults aged $\geq 60$ years, hypertension medications should be recommended when systolic and diastolic blood pressures are $>150 \mathrm{mmHg}$ and $>90 \mathrm{mmHg}$, respectively.
4. For patients with diabetes mellitus, our latest local clinical guidelines state that target blood pressure is $<140 / 80 \mathrm{mmHG}$, while JNC 8 uses the threshold of $<140 / 90 \mathrm{mmHg}$, i.e. both guidelines agree on the target systolic blood pressure of $<140 / 80 \mathrm{mmHg}$, but differ slightly in the target diastolic blood pressure.

5. For patients with chronic kidney disease or diabetes mellitus (regardless of age), the target systolic and diastolic blood pressures should be $<140 \mathrm{mmHg}$ and $<90 \mathrm{mmHg}$, respectively. 
6. If the target blood pressure is not reached within a month of treatment, the dosage of the initial drug should be increased, or a second drug from one of the recommended classes should be added.

7. Our local clinical practice guidelines recommend an angiotensin-converting-enzyme inhibitor (ACEI) or angiotensin receptor blocker (ARB) to be included as part of the antihypertensive regimen for people with type 2 diabetes mellitus requiring pharmacotherapy for hypertension, unless it is not well tolerated.

8. It is not advisable to use an ACEI and ARB together in the same patient.

You explained to the patients the recent international review of clinical evidence and current local guidelines. The target blood pressure for Mr Wolfgang, who has uncomplicated diabetes mellitus, should be below 140/80 mmHg, while that for Mrs Wolfgang should be below 150/90 mmHg. As the trend of Mr Wolfgang's diastolic blood pressure had been above $80 \mathrm{mmHg}$, he could benefit from starting on either an angiotensin-converting-enzyme inhibitor or angiotensin receptor blocker class of medication, according to our local guidelines. Mrs Wolfgang's blood pressure is, however, tolerable for her age. You wrote a short memo to your colleague with reference to the recommendations of the Joint National Committee 8 and Ministry of Health Clinical Practice Guidelines on Diabetes Mellitus (March 2014).
ABSTRACT Hypertension is the most common chronic condition seen in primary care. It is a potentially modifiable risk factor for cardiovascular and renal complications. The latest Joint National Committee recommendations in 2014 address common clinical questions from the best available science with regard to managing patients with hypertension. We review some of these recommendations and discuss how they may be applied in our practice.

Keywords: blood pressure, hypertension, Joint National Committee

\section{REFERENCES}

1. Lim SS, Vos T, Flaxman AD, et al. A comparative risk assessment of burden of disease and injury attributable to 67 risk factors and risk factor clusters in 21 regions, 1990-2010: a systematic analysis for the Global Burden of Disease Study 2010. Lancet 2012; 380:2224-60.

2. Chobanian AV, Bakris GL, Black HR, et al. The Seventh Report of the Joint National Committee on Prevention, Detection, Evaluation, and Treatment of High Blood Pressure: the JNC 7 report. JAMA 2003; 289:2560-72.

3. Epidemiology and Disease Control Division, Ministry of Health, Singapore. National Health Survey 2010 Report [online]. Available at: http://www.moh.gov.sg/content/dam/moh_web/Publications/ Reports/2011/NHS2010\%20-\%20low\%20res.pdf. Accessed August 1, 2014.

4. James PA, Oparil S, Carter BL, et al. 2014 evidence-based guideline for the management of high blood pressure in adults: report from the panel members appointed to the Eighth Joint National Committee (JNC 8). JAMA 2014; 311:507-20.

5. Ministry of Health, Singapore. Clinical Practice Guidelines 1/2014 Diabetes Mellitus [online]. Available at: http://www.moh.gov.sg/content/ dam/moh_web/HPP/Doctors/cpg_medical/current/2014/diabetes_mellitus/ cpg_Diabetes\%20Mellitus\%20Booklet\%20-\%20Mar\%202014.pdf. Accessed August 1, 2014 


\section{SINGAPORE MEDICAL COUNCIL CATEGORY 3B CME PROGRAMME} (Code SMJ 201408A)

1. Hypertension is a global health issue with a potential risk for long-term cardiovascular and renal complications.

2. The majority of patients with high blood pressure experience symptoms in the early stages and seek treatment from their primary care doctors.

3. The majority of patients are unaware of their hypertension, as they do not experience any symptoms.

4. The systolic blood pressure (SBP) measures the pressure in the heart when it squeezes.

5. The diastolic blood pressure (DBP) measures the pressure in the blood vessels when the heart relaxes.

6. As an individual's blood pressure is fairly constant, a clinical measurement of SBP $>140 \mathrm{mmHg}$ or DBP $>90 \mathrm{mmHg}$ can be diagnostic of hypertension.

7. In Singapore, the 2010 National Health Survey showed a slight decrease in crude prevalence, from $27.3 \%$ in 1998 to $24.9 \%$ in 2004 and $23.5 \%$ in 2010.

8. Although the Singapore Ministry of Health Clinical Practice Guidelines (MOH CPG) on hypertension (2005) was withdrawn, other CPGs such as the MOH CPG on Diabetes Mellitus (2014) can be crossreferenced for any updated blood pressure targets.

9. The Joint National Committee 8 (JNC 8) initial approach to the medical literature was restricted to randomised controlled trials, and hence, its recommendations may differ from those of previous JNC reports and other CPGs that included a range of study designs in their reviews.

10. For patients aged $<60$ years, it is recommended to initiate pharmacologic treatment to reach a target $\mathrm{SBP}<140 \mathrm{mmHg}$ and $\mathrm{DBP}<90 \mathrm{mmHg}$.

11. For patients aged $\geq 60$ years, it is recommended to initiate pharmacologic treatment to reach a target $\mathrm{SBP}<140 \mathrm{mmHg}$ and $\mathrm{DBP}<90 \mathrm{mmHg}$.

12. According to the JNC 8, it is recommended that patients aged $\geq 18$ years with chronic kidney disease (CKD) be initiated on pharmacologic treatment to reach a target $\mathrm{SBP}<140 \mathrm{mmHg}$ and $\mathrm{DBP}<90 \mathrm{mmHg}$.

13. According to the MOH CPG on Diabetes Mellitus 2014, patients with type 2 diabetes mellitus who have hypertension should be treated to reach a target $\mathrm{SBP}<140 \mathrm{mmHg}$ and $\mathrm{DBP}<80 \mathrm{mmHg}$.

14. The MOH CPG on Diabetes Mellitus 2014 recommends that patients with type 2 diabetes mellitus and hypertensive patients with type 2 diabetes mellitus have the same target DBP (i.e. treatment to reach a target $\mathrm{SBP}<140 \mathrm{mmHg}$ and $\mathrm{DBP}<80 \mathrm{mmHg}$ ).

15. An angiotensin-converting-enzyme inhibitor (ACEI) or angiotensin receptor blocker (ARB) should be included as part of the antihypertensive regimen for people with type 2 diabetes mellitus requiring pharmacotherapy for hypertension, unless it is not well tolerated.

16. For patients aged $\geq 18$ years with $C K D$, initial (or add-on) antihypertensive treatment should include an ACEI or ARB to improve kidney outcomes.

17. The recommended review period, should the patient fail to reach the target blood pressure, should be within a month of treatment.

18. If the target blood pressure cannot be attained with two drugs, a third drug should not be started without further investigations.

19. Do not use ACEI and ARB together in the same patient.

20. Referral to a specialist may be indicated for patients in whom the target blood pressure cannot be attained.

\section{Doctor's particulars:}

Name in full

MCR number

Email address

Specialty:

\section{SUBMISSION INSTRUCTIONS:}

(1) Log on at the SMJ website: http://www.sma.org.sg/publications/smjcurrentissue.aspx and select the appropriate set of questions. (2) Provide your name, email address and MCR number. (3) Select your answers and click "Submit".

RESULTS:

(1) Answers will be published in the SMJ October 2014 issue. (2) The MCR numbers of successful candidates will be posted online at the SMJ website by 30 September 2014. (3) Passing mark is $60 \%$. No mark will be deducted for incorrect answers. (4) The SMJ editorial office will submit the list of successful candidates to the Singapore Medical Council. (5) One CME point is awarded for successful candidates. 